\title{
The influence of motivations and barriers in the benefits. An empirical study of EMAS certified business in Spain
}

\author{
José Álvarez-García a, *, María de la Cruz del Río-Rama ${ }^{\text {b }}$, Margarida Saraiva ${ }^{\text {c, }}$ \\ António Ramos Pires ${ }^{d}$ \\ a Department of Financial Economics and Accounting, University of Extremadura, Faculty of Business, Finances and Tourism, Avenida de la Universidad, No. \\ 47, Cáceres (Spain) 10071, Caceres, Spain \\ ${ }^{\mathrm{b}}$ Department Business Organisation and Marketing, University of Vigo, Faculty of Business Administration and Tourism, As Lagoas, s/n, 32004, Orense, \\ Spain \\ ${ }^{\mathrm{C}}$ University of Évora and BRU-UNIDE/ISCTE-IUL, Largo dos Colegiais no. 2, 7000-803, Évora, Portugal \\ d Polytechnic Institute of Setúbal, Campus do IPS, Estefanilha, 2910-761, Setúbal, Portugal
}

\section{A R T I C L E I N F O}

Article history:

Available online 5 March 2018

\section{Keywords:}

Environmental management system

Eco-management and audit scheme

EMAS

Motivations

Barriers

Benefits

\begin{abstract}
A B S T R A C T
The main objective of this research is to analyze through a structured questionnaire, the influence of the motivations that lead companies to implement Eco-Management and Audit Scheme (EMAS) and the barriers found in the benefits perceived by companies, as well as, the degree of difficulty perceived for the implementation of the different requirements to be fulfilled, which are established in the regulation. An extensive review of the academic literature published on motivations, barriers, difficulties and benefits in environmental standards has been carried out in order to establish the working hypotheses which refer to the relationship between motivations, barriers with the benefits and degree of difficulty in implementing the requirements. The empirical investigation was carried out in a sample of 114 of the 255 companies of the Autonomous Community of Galicia (Spain) that have EMAS certification. The methodology used was the use of the application of a regression analysis to test the hypotheses; previously the measurement scales were validated and an exploratory factorial analysis was applied in order to determine the structure of the different variables considered in the study. The results show that the motivations affect the benefits positively and on the contrary, affect the barriers negatively (reduce them) and it was observed that the greater the barriers, the lower the benefits obtained from the implementation of EMAS (negative influence). The proposed regression models show the joint influence of the motivations and barriers on the benefits considered.
\end{abstract}

๑) 2018 Published by Elsevier Ltd.

\section{Introduction}

At present, both governments and society have become aware of the negative effects of economic development on the environment, so they put pressure on companies as a significant source of environmental degradation to take measures to minimize the negative impact of their activity on their environment (Claver and Molina, 2000). In this regard, the companies in their process of adaptation to environmental legislation, as well as, to current demands and concerns in the environmental field of consumers and the

\footnotetext{
* Corresponding author.

E-mail addresses: pepealvarez@unex.es (J. Álvarez-García), delrio@uvigo.es (M.C. del Río-Rama), msaraiva@uevora.pt (M. Saraiva), antonio.pires@estsetubal. ips.pt (A. Ramos Pires).
}

society in general have adopted as an integral part of their Management System an Environmental Management System (EMS) (Conde et al., 2003:45). This system allows them to understand and evaluate the environmental impact of their activities and to establish environmental objectives and targets (Cascio et al., 1996; Del Brio et al., 2001; Testa et al., 2014).

Thus, companies mainly use the international standard ISO 14001 (standard created by the International Organization for Standardization-ISO) or the EMAS Regulation (Eco-Management and Audit Scheme) as voluntary frameworks for the implementation of an EMS (Testa et al., 2014). These standards allow companies through a systematic and structured framework to develop an environmental policy, include environmental aspects (Boiral and Sala, 1998) and carry out environmental management. This management, according to Casadesús et al. (2005:231) is understood as 